\title{
Antibiogram Assay and Pathogenesis of Staphylococcus aureus in Baby Chicks
}

\section{Salama Rehab ${ }^{1,2 *}$, Akira Kubota ${ }^{2}$, Yusuke Kawai ${ }^{2}$, Ahmed Ibrahim ${ }^{3}$, Dina M.W. Shibat El- HaMD $^{4}$, Nabila OSMan ${ }^{3}$}

${ }^{1}$ Department of Poultry Diseases, Faculty of Veterinary Medicine, Aswan University, 81528, Egypt; ${ }^{2}$ Department of Veterinary Medicine, Obibiro University of Agriculture and Veterinary Medicine, 2-11 Inada, Obibiro, Hokkaido, 080-8555, Japan; ${ }^{3}$ Department of Poultry Diseases, Faculty of Veterinary Medicine, South Valley University, Qena, 83523, Egypt; ${ }^{4}$ Department of Poultry Diseases, Qena Regional Laboratory, Animal Health Research Institute, Agriculture Research Center (ARC), Qena, 83523, Egypt.

\begin{abstract}
Intensive usage of antibiotics in the poultry sector has become a major area of concern with the consequent emergence of antibiotic-resistant bacteria (ARB) and accordingly their access into the food chain, thus threatening the human health. In the current study, A total of 250 specimens from different local hatcheries of Luxor province (southern Egypt) have been examined for the incidence of Staphylococcus aureus using standard microbiological methods and biochemical tests. The overall prevalence was $27.60 \%(n=69 / 250)$. Only 30 isolates have been screened for in vitro drug sensitivity bioassay against 18 antimicrobial discs. Our findings revealed that all isolates showed high resistance against $\beta$-lactams, including oxacillin ( $83.33 \%, n=25 / 30)$, ampicillin $(80.00 \%, n=24 / 30)$, penicillin $(73.33 \%, n=22 / 30)$, and amoxicillin $(60.00 \%, n=18 / 30)$. On the other hand, the highest susceptibility was shown for vancomycin $(93.33 \%$, $n=28 / 30)$, trimethoprim sulpha methoxazole $(80.00 \%, n=24 / 30)$, and chloramphenicol $(70.00 \%, n=21 / 30)$. Results from a pathogenicity study conducted on 300 one-day-old chicks (SPF) manifested the highest mortality rate of $34.00 \%$ in one infected group, and most deaths were in the first three days of all infected groups. Based on the current study, constant monitoring of antibiotic susceptibility phenotypes is deemed prudent and necessary for evaluating the utility of certain antibiotics for treating $S$. aureus infections. Additionally, any alteration of resistance over the years should be identified, and all centers in charge must determine their own resistance profiles, as reducing the rate of antibiotic resistance will contribute to reducing the cost of treatment. Such measures can lead to improvement of the poultry industry, which represents a vital source of economy in Egypt.
\end{abstract}

Keywords | Baby chicks, Pathogenicity index, Prevalence, Sensitivity bioassay, S. aureus

Received | March 10, 2021; Accepted | June 21, 2021; Published | September 25, 2021

*Correspondence | Rehab Youssef Salama, Department of Veterinary Medicine, Obihiro University of Agriculture and Veterinary Medicine, Nishi 2-11 Inadacho, Obihiro, Hokkaido 080-8555, Japan; Email: rehabyousif@vet.aswu.edu.eg

Citation | Rehab S, Kubota A, Kawai Y, Ibrahim A, El-Hamd DMWS, Osman N (2021). Antibiogram assay and pathogenesis of Staphylococcus aureus in baby chicks. Adv. Anim. Vet. Sci. 9(11): 1844-1850.

DOI | http://dx.doi.org/10.17582/journal.aavs/2021/9.11.1844.1850

ISSN (Online) | 2307-8316; ISSN (Print) | 2309-3331

Copyright $\odot 2021$ Rehab et al. This is an open access article distributed under the Creative Commons Attribution License, which permits unrestricted use, distribution, and reproduction in any medium, provided the original work is properly cited.

\section{INTRODUCTION}

Ctaphylococcus spp. are substantial commensal pathogens of medical and veterinary prominence, and they have the potential to cause life-threatening disorders in several susceptible hosts (Gosbell and Van Hal, 2013). It is easily spread between animals and under certain conditions to humans through dermal infection or direct contact with animal excretions such as saliva, or through aerosols released during coughing and sneezing. Among several Staphylococcus spp., S. aureus is the most common and frequent pathogen causing food poisoning and foodrelated infections (Costa et al., 2012). Furthermore, $S$. aureus can compromise the poultry industry by causing 
severe economic losses due to reduced farm productivity and increased culls rate during processing (Jordan and Pattison, 1996).

Animal sources of Staphylococcus strains can potentially be harmful to humans, as most strains show resistance to antibiotics and cause zoonoses (Stapleton and Taylor, 2002).

In general, $25 \%$ of people are carriers for $S$. aureus according to studies conducted by the Centers for Disease Control and Prevention in 2011; infections vary from superficial skin infections to fatal disease (CDC, 2011). The severity of illness depends on several factors, among them the emergence of antibiotic-resistant strains which contribute to the evolution of methicillin-resistant $S$. aureus (MRSA). Poultry products are a potential source of transmitting antibiotic-resistant Staphylococcus strains to humans, manifesting as food-borne infections (Abulreesh and Organji, 2011).

Poor hygienic and sanitary conditions, along with a shortage of data about the health status of local hatcheries in the Luxor Province, motivated us to explore the existence of microbial load, particularly $S$. aureus pathogen in the first week following hatching.

In the present study, we investigate $S$. aureus significance inside local hatcheries of the Luxor province and explore the antibiotic resistance evolution within poultry farms by conducting a phenotypic characterization of isolated strains from baby chicks. Furthermore, we screened for their susceptibility toward commonly used antibiotics followed by a pathogenicity study for the same isolated strains.

\section{MATERIALS AND METHODS}

\section{STUdy AREA}

The study was conducted at local hatcheries of the Luxor province, southern Egypt, in which five sub-districts were included: Esna, Arment, El-Monshah, El-Tode, and ElHebil, as shown in Table 1.

\section{SAMPLING}

All chicks were subjected to necropsy before sampling in order to record any gross lesions on their viscera, especially for the yolk sac. Post-mortem examination was done according to Chauhan and Roy (2007). After necropsy, yolk sac samples were collected aseptically using sterile swabs, and transferred to Tryptic-soy broth in sterile test tubes until they were submitted for bacteriological examination in the reference lab for control on poultry production, Luxor, Egypt. All samples were collected under aseptic conditions and safety precautions according to Kitai et al. (2005); Lee (2003); Middleton et al. (2005); Rodgers et al. (2003); Rosky and Hamdy (1972); Swayne et al. (1998). Organs including liver and yolk material were collected from live diseased or freshly dead one day old baby chicks.

Table 1: Number and sources of samples collected from different local hatcheries of Luxor Province.

\begin{tabular}{llll} 
Sample sources & \multicolumn{2}{c}{ Diseased baby chicks } & $\begin{array}{l}\text { Dead in shell } \\
\text { Embryo }\end{array}$ \\
& Liver & Yolk sac & \\
Esna & 17 & 13 & 20 \\
\hline Arment & 15 & 15 & 20 \\
EL-Monshah & 11 & 19 & 20 \\
EL-Tode & 9 & 21 & 20 \\
EL-Hebail & 15 & 15 & 20 \\
Total & 67 & 83 & 100
\end{tabular}

The study protocol was approved by the committee of animal welfare and ethics, Laboratory Animal Control Guidelines of the Animal Health Research Institute, Cairo, Egypt.

\section{STAPHYLOCOCCUS AUREUS ISOLATION AND}

\section{IDENTIFICATION}

Pre-enriched nonselective medium (buffered peptone water) was inoculated with the collected samples at ambient temperature and then incubated at $37^{\circ} \mathrm{C}$ for 24 $\mathrm{h}$ under aerobic conditions. A loopful of the inoculated medium was transferred onto blood agar and then incubated for $24 \mathrm{~h}$ at $37^{\circ} \mathrm{C}$. Another loopful of enriched broth was sub-cultured on Mannitol Salt Agar (MSA) and incubated at $37^{\circ} \mathrm{C}$ for $24 \mathrm{~h}$, then confirmed on Baird Parker's Agar (BPA) containing egg yolk tellurite (EYT) and incubated at $37^{\circ} \mathrm{C}$ for $48 \mathrm{~h}$ in ambient air. Presumptive colonies were collected and maintained for gram stains and characterization by oxidase test, coagulase test, and slide catalase test according to Quinn et al. (2002). Suspected colonies were identified on the basis of staining reaction, cellular morphology, and hemolytic pattern on blood agar according to Swayne et al. (1998).

\section{ANTIMICROBIAL SUSCEPTIBILITY TEST}

Only $30 \mathrm{~S}$. aureus isolates were screened for in vitro antimicrobial susceptibility against a panel of 18 antimicrobials discs as shown in Table 3.

Profiling was conducted by the Kirby-Bauer disk diffusion method on Mueller-Hinton Agar (Bauer et al., 1966; CLSI, 2014). Plates were inverted and incubated at $35^{\circ} \mathrm{C}$ for $24 \mathrm{~h}$. Diameters of inhibition zones were measured, and results were interpreted as sensitive (S), intermediate (I), and resistant (R) according to CLSI (2014). 
Table 2: Overall and individual prevalence of $S$. aureus isolated from different tissues in each subdistrict.

\begin{tabular}{lllllll} 
Source & \multicolumn{3}{c}{ Coagulase +ve\% } & \multicolumn{3}{c}{ Coagulase -ve\% } \\
& \multicolumn{2}{c}{ Diseased baby chicks } & Dead-in-shell & \multicolumn{2}{c}{ Diseased baby chicks } & \multicolumn{1}{c}{$\begin{array}{l}\text { Dead-in-shell } \\
\text { Embryo }\end{array}$} \\
& Liver & Yolk sac & Embryo & Liver & Yolk sac & 15.00 \\
Esna & 11.76 & 76.92 & 25.00 & 88.24 & 23.08 & 20.00 \\
Arment & 6.67 & 46.67 & 30.00 & 93.33 & 53.33 & 15.00 \\
EL-Momshah & 9.09 & 15.79 & 40.00 & 90.90 & 84.21 & 40.00 \\
EL-Tode & 22.22 & 23.81 & 20.00 & 77.77 & 76.19 & 40.00 \\
EL-Hebail & 6.67 & 26.67 & 45.00 & 93.33 & 73.33 & 26.00 \\
Total & 11.94 & 34.94 & 32.00 & 89.55 & 65.06 &
\end{tabular}

Table 3: Phenotypic profile of antibiogram assay of S. aureus against 18 antimicrobials according to CLSI, 2014.

\begin{tabular}{|c|c|c|c|c|}
\hline \multirow[t]{2}{*}{ Antimicrobial discs } & \multirow[t]{2}{*}{ Classification } & \multicolumn{3}{|c|}{ S. aureus \% } \\
\hline & & Resistant & Sensitive & Intermediate \\
\hline Oxacillin & $\beta$-lactam & 83.33 & 13.00 & 3.67 \\
\hline Ampicillin & $\beta$-lactam & 80.00 & 20.00 & 0.00 \\
\hline Penicillin G & $\beta$-lactam & 73.33 & 26.67 & .000 \\
\hline Norfloxacin & Fluoroquinolone & .0070 & 23.33 & 6.67 \\
\hline Clindamycin & Lincosamide & .0070 & .0030 & .000 \\
\hline Streptomycin & Aminoglycoside & 63.33 & .0033 & 6.67 \\
\hline Amoxycillin & $\beta$-lactam & .0060 & 16.67 & 23.33 \\
\hline Tetracycline & Tetracycline & 56.67 & .0040 & 3.33 \\
\hline Neomycin & Aminoglycoside & 56.67 & .0037 & 6.33 \\
\hline Oxytetracycline & Tetracycline & .0055 & .0045 & .000 \\
\hline Erythromycin & Macrolide & .0050 & .0020 & .0030 \\
\hline Spectinomycin & Aminoglycoside & .0050 & 33.33 & 6.67 \\
\hline Amikacin & Aminoglycoside & .0050 & .0030 & .0020 \\
\hline Gentamicin & Aminoglycoside & 43.33 & .0030 & 16.67 \\
\hline Enrofloxacin & Fluoroquinolone & .0030 & .0050 & .0020 \\
\hline Chloramphenicol & Chloramphenicol & 26.67 & .0070 & 3.33 \\
\hline Trimethoprim-Sulpha & $\begin{array}{l}\text { Folate pathway antag- } \\
\text { onist }\end{array}$ & 16.67 & .0080 & 3.33 \\
\hline Vancomycin & Glycopeptide & 6.67 & 93.33 & .000 \\
\hline
\end{tabular}

\section{Pathogenicity STudy}

A total of 300 one-day-old baby chicks (SPF) were used for the pathogenicity study of $S$. aureus isolates. Chicks were divided into 6 equal groups (A-F), each one consisting of 50 birds, randomly chosen.

Groups (A to E) were infected once orally by $10^{6}$ dilutions of the same isolated strains from different hatchery locations (Esna, Arment, El -Monshah, El-Tode, and ElHebail), respectively. Group F was injected with nutrient broth and served as a negative control. All chick groups were kept separate and received a starter ration without any medication.
The temperature was maintained between $21^{\circ} \mathrm{C}$ and $25^{\circ} \mathrm{C}$, and relative humidity was (30-40\%) with a $12-\mathrm{h}$ photoperiod. Birds were observed daily for 10 days, during which clinical signs and mortality were recorded. After 10 days, all the remaining live birds were euthanized for postmortem scoring.

\section{RESULTS AND DISCUSSION}

Prevalence of coagulase + VE $S$. Aureus from baby CHICKS AND DEAD IN-SHELL EMBRYOS

Staphylococcosis has a crucial influence on veterinary and medical sectors. In poultry, it is correlated with several 
clinical disorders such as tenosynovitis, omphalitis, femoral head necrosis, infected hock and stifle joints, and bumblefoot (Suleiman et al., 2013). S. aureus has been recognized as the second most important bacterium accountable for yolk sac infections (Chauhan and Roy, 2007; Rehman et al., 1996).

Our findings revealed that overall prevalence of $S$. aureus was $27.60 \%$ as coagulase positive $(n=69 / 250)$, while coagulase-negative samples comprised $17.60 \% \quad(n=$ $44 / 250$ ) as shown in Table 2 . These results are in the line with those obtained by Shareef and Mansour (2009). Our prevalence was higher than Rizk and Bekhiet (2001), who identified $S$. aureus as $12.60 \%$ from chickens with facial edema, and Mohammed (2006), who reported 8.00\% incidence from chicken musculoskeletal abscesses. On the contrary, our results were lower than Zhu et al. (1999) who identified $49.00 \%$ of $S$. aureus isolates in live birds; (Amare et al., 2013) who isolated $41.67 \%$ from baby chicks, and Khalil and Enas (2012), who recorded a 20.00\% prevalence in litter samples from Behera (Egypt).

Yolk sac represents (20-25\%) of the live weight of a chick at birth, and it is usually resorbed during the first week (Khan et al., 2004). However, several factors contribute to the delay of yolk resorption resulting in its retention. Bacterial contamination is considered as the most frequently factor involved in this health problem. Our findings showed that yolk sacs from diseased baby chicks recorded a higher incidence for $S$. aureus $34.94 \%(n=29 / 83)$ than liver $11.94 \%$ (8/67), as shown in Table 2. This is attributed to the fact that Staphylococcus aureus is one of the significant factors for yolk sac infections in baby chicks.

\section{ANTIMICROBIAL SUSCEPTIBILITY ASSAY}

Poor husbandry practices with minimum levels of biosafety and biosecurity practices necessitate the overdependence and improper utilization of antibiotics as a prophylaxis or as growth promoters in poultry farms, and hence, these antibiotics have found wide clinical and veterinary applications with indiscriminate use in Egypt. The antimicrobial sensitivity profile of the current study exhibited that resistance of $S$. aureus to antibiotics varied considerably; the highest resistance was recorded to $\beta$-lactams including oxacillin (83.33\%), ampicillin (80.00\%), penicillin (73.33\%), and amoxicillin (60.00\%), as shown in Table 3.

Previous investigations demonstrated variant patterns of $S$. aureus resistance against penicillin, oxacillin, erythromycin, gentamicin, neomycin, and tetracycline (Nemati et al., 2008). Furthermore, Shareef and Mansour (2009) reported that $S$. aureus isolates tolerated two antimicrobials (ampicillin and amoxicillin), which agreed with our study.
On the contrary, graded sensitivity was observed for other antimicrobials such as gentamycin, chloramphenicol, penicillin, and erythromycin, while $100 \%$ sensitivity was demonstrated to enrofloxacin. Our investigations were also in agreement with those of Losito et al. (2005), who reported that all $S$. aureus isolates were susceptible to vancomycin.

Antimicrobial agents sold in Egypt and other developing countries are combinations of several active components of these antibiotics at subtherapeutic/ substandard doses; consequently, a single drug may have mixed ingredients of those at a required dose. Limited policies for the regulation of drug acquisition, additionally with the use of several drug combinations, may contribute to the antimicrobial resistance observed in this study and other studies. As such, our findings may be congruous or may be lower or higher than others, due to the difference in conditions associated with the environment where this study has been conducted. Moreover, an organism's propensity to acquire antimicrobial resistance necessitates conducting a frequent susceptibility monitoring of the clinical isolates against commonly used antibiotics (Werckenthin et al., 2001; White et al., 2003).

\section{Pathogenicity STUdy}

The pathogenicity index was studied for 300 one-day-old chicks experimentally infected with the same 30 isolated strains from different hatcheries as mentioned above. All infected groups manifested general signs of depression: closed eyes, drooping wings, poor growth, weakness, huddling together, and watery diarrhea. Moreover, the umbilicus was inflamed with bluish-black discoloration and a pungent odor. The abdomen felt soft, mushy, flabby, and enlarged. In contrast, the control group remained active throughout the experimental period. Additionally, all infected birds were off-feed and water as reported before by Moustafa and Hussein (1999). On the other hand, significant post-mortem lesions exhibited air sacculitis and pericarditis with fibrinous exudates. In addition, congestion of breast and thigh muscles with unabsorbed yolk sac and petechial hemorrhages on the coronary fat were found. Congestion of liver and kidney with septicemia was observed in some birds.

Infected yolk sac weight/body-weight ratio was higher than the control group (data not shown). These observations were expounded as the weight of the unabsorbed yolk was higher, while body weight was lower in all infected groups. Our findings were similar with those observed by Anjam (1997), Khan et al. (2002).

The mortality rate post-infection is shown in Table 4; variant patterns have been observed among infected 
groups due to assorted virulence between isolated strains, according to different localities. The data revealed that group (A) infected with S. aureus (from Esna) demonstrated the highest mortality (34.00\%), and most deaths were in the first 3 days after hatching. This may explain the severity of these isolates, which showed the highest resistant among others in the antibiogram assay. This interpretation seems reasonable, as the Esna territory is recognized by massive poultry production without establishment of proper hygienic measures, combined with intensive abuse of antimicrobial agents without regulations.

Table 4: Mortality pattern of experimentally infected baby chicks.

\begin{tabular}{llllll}
$\begin{array}{l}\text { S. aureus } \\
\text { sources }\end{array}$ & $\begin{array}{l}\text { Mortality } \\
\mathbf{\%}\end{array}$ & \multicolumn{4}{c}{ Mortality/day } \\
Esna & 34.00 & 11 & 4 & 1 & 1 \\
\hline Arment & 26.00 & 7 & 3 & 2 & 1 \\
\hline E1-Monshah & 12.00 & 3 & 1 & 1 & 1 \\
\hline E1-Tode & 14.00 & 5 & 2 & 0 & 0 \\
E1-Hebail & 10.00 & 4 & 1 & 0 & 0 \\
Control & 0.00 & 0 & 0 & 0 & 0
\end{tabular}

Re-isolation of $S$. aureus from experimentally infected birds demonstrated that yolk sacs recorded the highest rate amongst all infected groups, followed by liver and heart as shown in Table 5, which is in agreement with Devriese (1975) and Narine (1973).

Table 5: Prevalence of re-isolated S. aureus from dead chickens.

\begin{tabular}{llll|}
\hline $\begin{array}{l}\text { S. aureus } \\
\text { isolates }\end{array}$ & Yolk sac \% & Leisolated S.aureus \\
Group-A & 41.18 & 41.18 & Heart \% \\
\hline Group-B & 38.46 & 15.38 & 0.00 \\
Group-C & 50.00 & 50.00 & 16.67 \\
Group-D & 57.14 & 57.14 & 0.00 \\
\hline Group-E & 40.00 & 20.00 & 40.00 \\
\hline Group-F & 0.00 & 0.00 & 0.00
\end{tabular}

Since yolk is very rich in water and lipid, it promotes the rapid growth of pathogens. Additionally, the body temperature of the chick, higher than that of egg incubation, is an ideal factor for bacterial growth including Staphylococcus spp. That can lead to infection of the yolk sac (Khan et al., 2004), which represents the main cause of chick mortality during the first week post-hatching (Rai et al., 2005; Yassin et al., 2009). Consequent mortality ranging from $1.7 \%$ to $8.6 \%$ would cause high economic losses (Awobajo et al., 2007).

In the current survey, individual incidence of $S$. aureus was the same in yolk sacs and livers from hatcheries of Esna, El-Monshah and El-Tode: $41.18 \%, 50.00 \%$ and 57.00\%, respectively. On the contrary, prevalence of $S$. aureus was higher in yolk sacs than liver for hatcheries of Arment and El-Hebail. We could not compare the prevalence postinfection in hearts because we did not collect samples from heart tissues in the original survey.

\section{CONCLUSIONS AND RECOMMENDATIONS}

Based on the previous investigations, the following study fills a significant gap about $S$. aureus infections within local hatcheries of the Luxor province.

Despite the susceptibility of isolated strains to many antibiotics which may be effective for chickens in the first week of age, the emergence of multidrug-resistant bacteria presents a real danger to animal and human health. Further investigations are demanded to better control risk factors. Periodic surveillance programs are also needed to reduce the frequent use of antibiotics in poultry farms.

\section{ACKNOWLEDGEMENTS}

This work was funded in part with the Egyptian Ministry of Higher Education and Scientific. Research and Faculty of Veterinary Medicine, South Valley University. We would like to thank Assistant Professor Glen Hill of Obihiro University of Agriculture and Veterinary Medicine for checking the English of this manuscript.

\section{NOVELTY STATEMENT}

Our study provided the 1 st survey to investigate the incidence of S. aureus among chicken embryos of Luxor province. Furthermore, our isolates exhibited resistance toward $\beta$ lactam and other antibiotics which may be acquired from their hens, and consequently, this is alarm that resistance gene can be transmitted through progeny.

\section{AUTHOR'S CONTRIBUTION}

All authors contributed equally to the manuscript.

\section{CONFLICT OF INTEREST}

The authors have declared no conflict of interest.

\section{REFERENCES}

-Abulreesh HH, Organji SR (2011). The prevalence of multidrugresistant Staphylococci in food and the environment of Makkas, Saudi Arabia. Res. J. Microbiol., 6(6): 510-523. https://doi.org/10.3923/jm.2011.510.523 
- Amare A, Ali MA, Ashenafi S, Shahid N, Haileleul N (2013). Yolk sac infection (Omphalitis) in Kombolcha Poultry Farm, Ethiopia. Am. Eur. J. Sci. Res., 8(1): 10-14.

-Anjum AD (1997). Poultry Diseases, $2^{\text {nd }}$ ed. Veterinary Agriculture Publication, Faisalabad. Pakistan, pp. 178-180.

-Awobajo OK, AKintan YM, Igbosanu AO, Mako AA, Olatokunbo OT (2007). The mortality rate in the two breeds of broiler on breeding stage. World Appl. Sci. J., 2(4): 304308.

- Baba K, Ishihara K, Ozawa M, Usui M, Hiki M, Tamura Y, Asai T (2012). Prevalence and mechanism of antimicrobial resistance in Staphylococcus aureus isolates from diseased cattle, swine and chickens in Japan. J. Vet. Med. Sci., 74: 561-565. https://doi.org/10.1292/jvms.11-0357

- Bader HM (2008). Microbiological studies on Staphylococcus aureus with regard to antibiotic resistance. MV Sci. thesis Fac. Vet. Med. Microbiolog.,

- Bauer AW, Kirby WM, Sherris JC, Turck M (1966). Antibiotic susceptibility testing by a standardized single disk method. Am.J.Clin.Pathol., 45(1): 493-496.https://doi.org/10.1093/ ajcp/45.4_ts.493

- Centers for Disease Control and Prevention (2011). Staphylococcus aureus in healthcare settings.

- Chauhan HVS, Roy S (2007). Poultry diseases diagnosis and treatment $3^{\text {rd }}$ ed. New Delhi, India: New Age International (P) Ltd. Publishing. pp. 152-157.

- Choudhury BA, Chanda P, Dasgupta RK, Dutta LS, Bhuin S, Saha L, Bhuin S (1993). Studies on yolk sac infection in poultry: antibiogram of isolates and correlation between invitro and in-vivo drug action. Indian J. Anim. Health, 32(1): 21-23.

- Clinical Laboratory Standards Institute (2014). Performance standards for antimicrobial susceptibility testing: Eighteenth informational supplement. Clinical Laboratory Standards Institute; Wayne, PA, USA; CLSI Document M100-S18.

- Costa LF, Paixão TA, Tsolis RM, Bäumler AJ, Santos RL (2012). Salmonellosis in cattle: Advantages of being an experimental model. Res. Vet. Sci., 93(1): 1-6. https://doi. org/10.1016/j.rvsc.2012.03.002

-Del' Alamo L, d'Azevedo PA, Strob AJ, Rodríguez-Lopez DV, Monteiro J, Andrade SS, Pignatari ACC, Gales AC (2007). An outbreak of catalase-negative methicillin-resistant Staphylococcus aureus. J. Hosp. Infect., 65(3): 226-230. https:// doi.org/10.1016/j.jhin.2006.12.005

-Devriese LA, Devos AH, Van Damme LR (1975). Quantitative aspects of the Staphylococcus aureus flora of poultry. Poult. Sci., 54(1): 95-101. https://doi.org/10.3382/ps.0540095

-El-Jakee J, Nagwa AS, Bakry M, Sahar AZ, El-gabry E, Gad E (2008). Characteristics of Staphylococcus aureus strains isolated from human and animal sources. Am. Eurasian J. Agric. Environ. Sci., 4(1): 221-229.

- Moustfa FA, Hussein SZ (1999). Gram-positive cocci causing septicaemia in chickens Assiut Governorate. Assiut. Vet. Med. J., 41(82): 227-238. https://doi.org/10.21608/ avmj.1999.182693

- Gosbell IB, Van Hal SJ (2013). Staphylococcus aureus colonisation: Some questions answered. Lancet Infect. Dis., 13(5): 380381. https://doi.org/10.1016/S1473-3099(13)70048-3

-Jordan FTW, Pattison M (1996). Poultry diseases, $4^{\text {th }}$ ed. Saunders, London. pp. 66-69.

-Khalil SA, Einas ES (2012). Aerobic bacteria associated with omphalitis of chicks. Alex. J. Vet. Sci., 37(1): 69-77.

-Khan K A, Khan S A, Hamid SH, Aslam A, Rabbani MA
(2002). Study on the pathogenesis of yolk retention in broiler chicks. Pak. Vet. J., 22 (4): 175-180.

- Khan KA, Khan SA, Aslam A, Rabbani M, Tipu MY (2004). Factors contributing to yolk retention in poultry. A review. Pak. Vet. J., 24(1): 46-50.

- Kitai S, Shimizu A, Kawano J, Sato E, Nakano C, Tatsuya Uji, Kitagawa H (2005). Characterization of methicillinresistant Staphylococcus aureus isolated from retail raw chicken meat in Japan. J. Vet. Med. Sci., 67(1): 107-110. https://doi. org/10.1292/jvms.67.107

- Lee JH (2003). Methicillin (Oxacillin)-resistant Staphylococcus aureus strains isolated from major food animals and their potential transmission to humans. Appl. Environ. Microbiol., 69(1): 6489-6494. https://doi.org/10.1128/ AEM.69.11.6489-6494.2003

- Lee HK, Kim JB, Kim H, Jekarl DW, Kim YR., Yu JK, Park YJ (2014). Clonal spread of catalase-negative ST5/SCC mec II Staphylococcus aureus carrying the staphylococcal enterotoxin A (sea), staphylococcal enterotoxin b (seb), and toxic shock toxin (tst) virulence genes. Ann. Clin. Lab. Sci., 44(4): 394398.

- Losito P, Vergara A, Muscariello T, Ianieri A (2005). Antimicrobial susceptibility of environmental Staphylococcus aureus strains isolated from a pigeon slaughterhouse in Italy. Poult. Sci., 84(11): 1802-1807. https://doi.org/10.1093/ ps/84.11.1802

-Middleton JR, Fales WH, Luby CD, Landsay Oaks J, Susan S, Kinyon JM, Wu CC, Maddox CW, Hartmann F (2005). Surveillance of Staphylococcus aureus in veterinary teaching hospitals. J. Clin. Microbiol., 43(6): 2916-2919. https://doi. org/10.1128/JCM.43.6.2916-2919.2005

- Moghney A (1998). In vitro and in vivo characterization of some pathogenic microorganisms isolated from broilers in Behera Province with special reference to the efficacy of Allium sativum "Garlic". Assiut. Vet. Med. J., 39(1): 334343. https://doi.org/10.21608/avmj.1998.183221

- Mohamed E (2006). Characterization of Staphylococcus aureus isolated from different sources with special reference to protein A. Master thesis Vet. Sci. Cairo Univ.,

- Nairn ME (1973). Bacterial osteomyelitis and synovitis of the turkey. Avian Dis., 17: 504-517. https://doi. org/10.2307/1589148

- Nemati M, Katleen H, Urszula L, Olivier D, Ariane D, Marc S, Luc AD, Frank P, Freddy H (2008). Antimicrobial resistance of old and recent Staphylococcus aureus isolates from poultry: First detection of livestock-associated methicillin-resistant strain ST398. Antimicrob Agents and Chemother. 52(10): 3817-3819. https://doi.org/10.1128/AAC.00613-08

- Otalu OJ, Kabir J, Okolocha EC, Umoh VJ (2011). Multi-drug resistant coagulase positive Staphylococcus aureus from live and slaughtered chickens in Zaria, Nigeria. Int. J. Poult. Sci., 10(11): 871-875. https://doi.org/10.3923/ijps.2011.871.875

- Quinn PJ, Carter ME, Markey BK, Donnoly WJ, Leonard FC (2002). Veterinary microbiology and microbial disease. Osney Mead, Oxford first LTd, Registered at the United Kingdom. pp. 166-1117.

- Rai M F, Khan SA, Aslam A, Saeed K (2005). Effect of yolk sac infection in chicken., Avian Poult. Boil. Rev., 16(2): 87-93. https://doi.org/10.3184/147020605783438804

-Rehman RM, Rabbani S, Khan A, Saleem CM (1996). Pathological aspects of early chick mortality due to bacterial infections. Pak. J. Sci. Res., 48(1): 101-107.

-Rizk MS, Bekhiet AA (2001). Bacteriological aspects of 
facial oedema in native and foreign chicken at Behera province. Assiut. Vet. Med. J., 45(90): 314-322. https://doi. org/10.21608/avmj.2001.180215

-Rodgers JD, McCullagh JJ, McNamee PT, Bell C, Brice N, Smyth JA, Ball HJ (2003). An investigation into the efficacy of hatchery disinfectants against strains of Staphylococcus aureus associated with the poultry industry. Vet. Rec., 53(1): 656-657. https://doi.org/10.1136/vr.153.21.656

- Roskey CT, Hamdy MK (1972). Bruised poultry tissue as a possible source of staphylococcal infection. Appl. Environ. Microbiol., 23(4): 683-687. https://doi.org/10.1128/ am.23.4.683-687.1972

- Shareef AM, Mansour RS, Ibrahim KK (2009). Staphylococcus aureus in commercial breeder layer flocks. Iraqi J. Vet. Sci., 23(1): 63-68.

- Sheldon BW, Brake J (1991). Hydrogen peroxide as an alternative hatching egg disinfectant. Poult. Sci. 70(5): 1092-1098. https://doi.org/10.3382/ps.0701092

- Suleiman A, Zaria LT, Grema HA, Ahmadu P (2013). Antimicrobial resistant coagulase positive Staphylococcus aureus from chickens in Maiduguri, Nigeria. Sokoto J. Vet. Sci., 11(1): 51-55. https://doi.org/10.4314/sokjvs.v11i1.8

- Stapleton PD, Taylor PW (2002). Methicillin resistance in Staphylococcus aureus: Mechanisms and modulation. Sci. Prog., 15(2): 57-72. https://doi. org/10.3184/003685002783238870

- Swayne DE, Charman GJR, Jackwood MW, Pearson JE, Reed WM (1998). Staphylococcosis, A laboratory manual for the Isolation and identification of avian pathogens, $4^{\text {th }}$ ed.

-Werckenthin C, Cardoso M, Jean L, Stefan S (2001). Antimicrobial resistance in Staphylococci from animals with particular reference to bovine. S. aureus, porcine $S$. byicus and Canine S. intermedius. J. Vet. Res., 32(3-4): 341-362. https://doi.org/10.1051/vetres:2001129

-White DG, Ayers S, Maurer JJ, Thayer SG, Hofacre C (2003). Antimicrobial susceptibilities of Staphylococcus aureus isolated from commercial broilers in Northeastern Georgia. Avian Dis., 47(1): 203-210. https://doi.org/10.1637/00052086(2003)047[0203:ASOSAI]2.0.CO;2

- Yassin H, Velthuis AGJ, Borjan M, Van RJ (2009). Field study on broilers first-week mortality. Poult. Sci. J., 88(4): 798804. https://doi.org/10.3382/ps.2008-00292

-Zhu XY, Wuc C, Hester PY (1999). Induction of the delayed foot bad and wattle reaction to killed Staphylococcus aureus in chickens. Poult. Sci. J., 78(3): 346-352. https://doi. org/10.1093/ps/78.3.346 